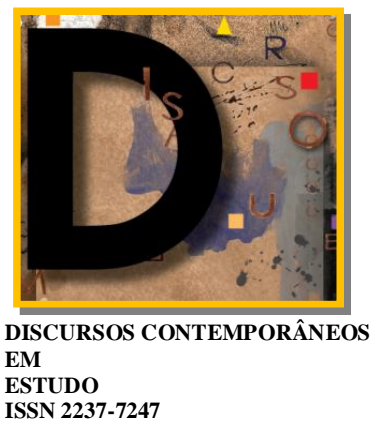

\title{
EM CARTAZ: HOLL YFRUTI. UM ESTUDO DA APROPRIAÇÃO CULTURAL COMO ESTRATÉGIA COMUNICACIONAL DA MARCA HORTIFRUTI
}

\author{
Elizete de Azevedo Kreutz, (Univates/RS) ${ }^{1}$ \\ Juliane Fröhlic Campos (Univates/RS) ${ }^{2}$
}

A Rede Hortifruti, maior distribuidora de frutas e verduras do Brasil, com sede no Estado do Espírito Santo, utiliza, em suas campanhas publicitárias, a filmografia hollywoodiana, em consonância com seu discurso multimodal. O objetivo deste estudo é verificar como a utilização de elementos do imaginário coletivo e do cotidiano das pessoas se torna uma importante ferramenta nas estratégias comunicacionais, que geram uma espécie de conexão emocional, ao passar por todas as fases: chamar a atenção do público, instigá-lo pela criatividade e pelo bom humor, interagir com ele e causar a sua identificação com a marca. Para isso, utilizamos a metodologia Hermenêutica de Profundidade, ancorada nas técnicas de pesquisa bibliográfica, entrevista e estudo de caso. Como resultado, esperamos que a pesquisa possa contribuir para a reflexão da importância de consolidar a marca por meio de uma comunicação estratégica e criativa.

Palavras-chave: Marca. Estratégias Comunicacionais. Imaginário. Hortifruti. Hollywood.

Hortifruti Network, the largest distributor of fruit and vegetables in Brazil, headquartered in the State of Espirito Santo uses in its advertising campaigns the Hollywood filmmaking, aligned with its multimodal speech. The aim of this study is to see how the use of elements of the collective imagination and those of everyday people life becomes an important tool in communication strategies, that generate a kind of emotional connection, passing through all stages: to call the attention of the public, to goad it by the creativity and humor, to interact and to cause the public identification with the brand. Therefore, we used depth hermeneutics method, grounded in the techniques of literature review, interview and case study. As a result, we expect that it may contribute to the reflection of the importance of building brand awareness through strategic and creative communications.

Keywords: Brand. Communication strategies. Imaginary. Hortifruti. Hollywood.

\footnotetext{
${ }^{1}$ Pós-doutora pela UnB, doutora e mestre em Comunicação Social pela PUCRS. Professora e pesquisadora da Univates, Lajeado/RS/Brasil.E-mail: eakreutz@bewnet.com.br.

2 Bacharel em Comunicação Social com Habilitação em Publicidade e Propaganda do Centro Universitário Univates, Lajeado/RS/Brasil. E-mail: julianefc@msbnet.com.br.
} 


\section{Introdução}

A gestão de marcas (branding) é um processo complexo que exige competência e desempenho transdisciplinar do profissional, que, por meio das estratégias comunicacionais, busca gerar mais do que valor à marca; busca conquistar os "fãs da marca" (ROZANSKI, 2002). Nesse sentido, a Rede Hortifruti, distribuidora de frutas e verduras do Brasil, utiliza inúmeras estratégias comerciais e realiza a comunicação integrada da marca, ou seja, faz uso do discurso multimodal (SILVESTRE et al., 2009) como forma de gestão desta.

No presente artigo, abordamos uma das estratégias comunicacionais adotadas pela empresa Hortifruti para criar uma interação interpretativa do leitor (visual-verbal), o qual nem sempre é o consumidor final dos produtos oferecidos. Essa interação tem provocado efeitos positivos nas pessoas, como empatia, prazer, curiosidade, além de gerar valor de marca, conquistando mais clientes, alguns deles, fãs da marca, e obtendo um valor superior de seus produtos perante os concorrentes, entre outras vantagens.

Nosso objetivo foi verificar como a publicidade pode ser criativa e eficiente ao se apropriar do imaginário coletivo, da cultura popular, com fins mercadológicos. Sendo assim, o estudo se justifica na medida em que constatamos a enorme taxa de "mortalidade infantil dos anúncios"3 (BROCHAND, 1999). Além disso, caracterizamos a Campanha Hollywood e verificamos quais são os elementos, na utilização de paródia de filmes, capazes de estabelecer uma aproximação com os públicos.

No mundo das marcas, para existir, é preciso chamar a atenção, entretanto, para sobreviver, é necessário entrar na mente dos públicos e, para se destacar, é fundamental fazer sentido para a vida desses públicos: interagir, emocionar, provocar experiências e a própria identificação do público com a marca.

Este estudo está baseado na metodologia da Hermenêutica de Profundidade (HP, conforme THOMPSON, 1995), que é dividida em três fases: análise do contexto sócio-histórico do caso escolhido; análise formal-discursiva (optamos pela semiótica, conforme PENN, 2002); e interpretação-reinterpretação, ou seja, apresentação das nossas considerações a respeito do estudo realizado. A HP está ancorada nas técnicas da pesquisa bibliográfica (AZEVEDO SOUZA apud KREUTZ, 2001), em entrevistas (BAUER; GASKELL, 2002) e na análise de caso (COBRA, 1991). Para melhor compreensão de como se dá a produção de sentido, abordamos também questões sobre o imaginário (DURAND, 1997).

\footnotetext{
${ }^{3}$ Brochand (1999) afirma que a maior parte dos anúncios passa despercebida pelos públicos e, desta forma, não atinge o seu objetivo.
} 
O estudo está assim organizado: breve contextualização sócio-histórica da citada empresa; análise dos cartazes da campanha "Hollywood": E o Coentro Levou, O Quiabo Veste Prada e Batatas do Caribe; e considerações finais a respeito do assunto.

\section{A Hortifruti e suas estratégias}

Os dados a respeito da Rede Hortifruti foram obtidos por meio de informações contidas na página oficial da empresa (2010), de dados fornecidos pela assessoria de imprensa da Rede Hortifruti (2009 e 2010), da agência responsável pela conta - MP Publicidade (2010) -, e de revistas especializadas, como a IstoÉ Dinheiro (2003).

A Hortifruti, cuja razão social é Hortifruti Hortigil S.A., é uma empresa familiar, que iniciou suas atividades em 1989, na cidade de Colatina no Espírito Santo. Hoje, com 3000 colaboradores, está presente nos estados do Rio de Janeiro e do Espírito Santo, com 21 lojas, por onde circulam mais de 13 milhões de clientes. Anualmente, a rede comercializa cerca de 150 mil toneladas de frutas, legumes e verduras.

A empresa é considerada a maior rede varejista de hortifrutigranjeiros do Brasil, e sua história peculiar justifica esse posicionamento da empresa no mercado. Em entrevista concedida à revista IstoÉ Dinheiro (2003, p. 46), o sócio majoritário, Gilberto Lopes, que até 1982 carregava caixas na Central de Abastecimento (Ceasa), explica a trajetória da empresa:

Enquanto caminha pelos corredores da Central de Abastecimento de Vila Velha (ES), Gilberto Lopes cumprimenta calorosamente os comerciantes. Inspeciona com rigor legumes e verduras e faz as encomendas do dia. A rotina se repete várias vezes na semana. Lopes conhece bem os segredos da Ceasa. Até 1982, ele fazia parte do exército de carregadores de caixas de madeira que dão expediente no local. Hoje, é dono de uma quitanda de luxo. Na verdade, uma rede que conta com 22 lojas espalhadas por cidades do Espírito Santo, Rio de Janeiro e São Paulo, cujas vendas somam R 120 milhões. "Foi uma decisão ousada apostar na qualidade em detrimento do preço baixo", avalia o empresário. (...) Fruto de uma aposta ousada do ex-carregador da Ceasa, o Hortifruti é, sem dúvida, um caso de sucesso no ramo varejista a começar pelo formato e o estilo de gestão. A idéia nasceu da cabeça de Lopes, enquanto ele trabalhava no sacolão Feira da Economia. Ousado, ele propôs o patrão Paulo Hertel trocar aquele tipo de negócio por algo diferenciado. "Não copiamos o modelo de nenhum supermercado ou empório. Fizemos tudo de modo intuitivo", conta Lopes. O segredo foi a capacidade de transpor para o ambiente 
fechado a atmosfera das feiras livres; com legumes e verduras frescas dispostas em tabuleiros de fácil acesso para o consumidor. Para diferenciar-se da concorrência, eles incluíram uma seção com produtos exóticos (importados da Ásia), além de uma seção de frios (laticínios e carnes silvestres) no cardápio (...) O "carregador" foi longe. Ao lado dos sócios, ele pilota um negócio que cresce a uma taxa superior a $15 \%$ ao ano, atende a um milhão de clientes e movimenta 13 mil toneladas de alimentos por ano.

Conforme a reportagem da revista, Gilberto Lopes é bastante empreendedor e visionário. Por meio de ações, a empresa diferenciou-se da concorrência: recriou as feiras livres em um ambiente bem mais agradável ao consumidor.

Como Gilberto Lopes preocupa-se com a plena satisfação do cliente, uma das estratégias da empresa foi monitorar os pontos de contato com os públicos, por exemplo, os hábitos em relação às mídias, e, dessa forma, gerenciar uma dinâmica de relacionamento que gere valor para todos os envolvidos. A Hortifruti está utilizando uma plataforma de multimídia, visando gerenciar os conteúdos que fazem parte da vida das pessoas.

Segundo Kreutz e Más Fernández (2009, p. 5), para analisar as estratégias comunicacionais de uma organização, é preciso considerar seus públicos e seus pontos de contato. Para os autores, “descobrir quem são seus públicos e seus pontos de contato é crucial para a sobrevivência da marca, pois, com essas informações, é possível desenvolver estratégias comunicacionais mais efetivas e eficientes".

O público da Hortifruti pode ser qualquer indivíduo ou grupo cujos interesses tenham a capacidade de influir, de alguma maneira, na organização, seja de forma positiva ou negativa. Segundo Guimarães (2003), os fatores que atuam na interferência da percepção dos públicos e no seu relacionamento com a organização são os físicos - como o PDV (ponto de venda), o preço das mercadorias, a distribuição - , e emocionais - como a capacidade de atribuir simpatia ou antipatia. Por tudo isso, a empresa tornou-se um referencial para quem procura uma vida saudável, pois, além de trabalhar com produtos frescos e selecionados, está sempre preocupada em oferecer variedade, conforto e economia a seus clientes.

Para conquistar o seu espaço e construir a maior rede de hortifrutigranjeiros do país, a empresa investiu não apenas em instalações e em qualidade de produtos, como também na comunicação. Observamos que as suas estratégias de comunicação mais usuais são: Brand Experience, Brand Cultural Entertainment, E-branding, Brand Comunication e Brand Community. 
Brand Experience é a estratégia que proporciona interação diferenciada e, no caso, holística, entre a marca e os seus públicos. A Hortifruti faz isso promovendo eventos sazonais, por exemplo, Dia da Mulher, Dia das Crianças, Dia dos idosos, entre outros. Patrocinou também o $1^{\circ}$ Piquenique Tamanho Família Hortifruti (figura 1), um evento para toda família. Para participar, os clientes precisaram apenas reunir sua família, levar seu lanche no dia e local combinados e se divertir. O evento, que se realizou no dia 24 de outubro, reuniu cerca de quatro mil pessoas (HORTIFRUTI, 2009, 2010).

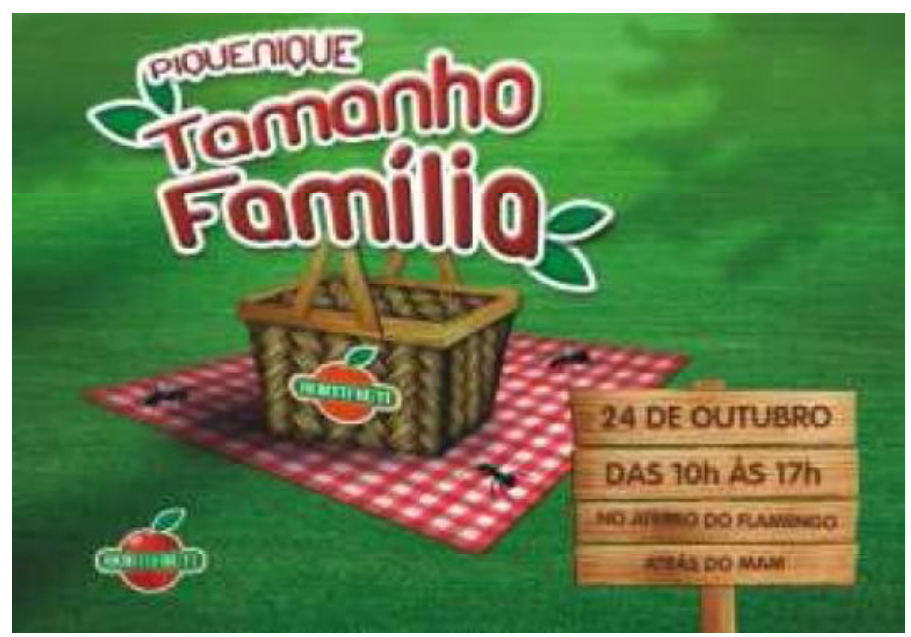

Fonte: Hortifruti (2010)

Figura 1 - Piquenique Tamanho Família

A empresa também cria eventos inusitados, como um vernissage (figura 2) ou uma exposição na estação do Metrô da Carioca. Essa é uma estratégia denominada Brand Cultural Entertainment (entretenimento), que se destaca como ferramenta fundamental para alcançar os objetivos de comunicação mercadológica, vinculando-se naturalmente ao público e à sua cultura (KREUTZ; MÁS FERNÀNDEZ, 2009).

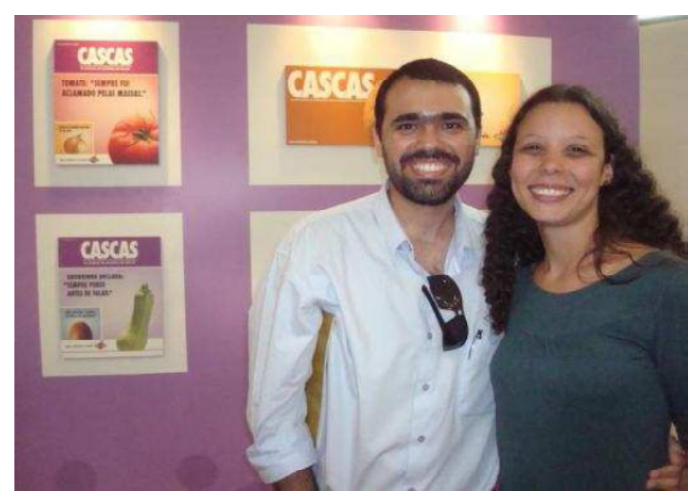

Fonte: HORTIFRUTI, 2010

Figura 2 - Exposição Hortifruti 
Outro exemplo dessa estratégia é a mostra Exposição Hortifruti: o caminho natural de um sucesso, que fez parte das comemorações dos 20 anos da empresa. Nela, os visitantes puderam fazer uma viagem no tempo pela comunicação de algumas das marcas mais queridas do Brasil.

O E-branding explora estratégias de comunicação on-line com a utilização de instrumentos da Web 2.0. A interatividade gerada pela comunicação da marca Hortifruti fez com que ela fosse muito comentada em inúmeros blogs, twitters, entre outros meios 2.0. A Brand Comunication (comunicação da marca), por sua vez, estabelece um relacionamento estreito entre o consumidor e sua marca. Quando essa marca consegue estabelecer uma conexão emocional com os seus públicos, é definida como Brand Community (comunidade), grupo de pessoas que se tornam admiradores, fãs da marca (KREUTZ; MÁS FERNÁNDEZ, 2009).

Observamos que, para divulgar a marca, os meios de comunicação mais utilizados pela Hortifruti foram site, rádio, newsletter, televisão e outdoors.

\subsection{Site Hortifruti}

Para ser coerente com o discurso da marca, o site da Hortifruti (Figura 3), www.hortifruti.com.br ${ }^{4}$, apresenta-se como uma verdadeira "salada de frutas":

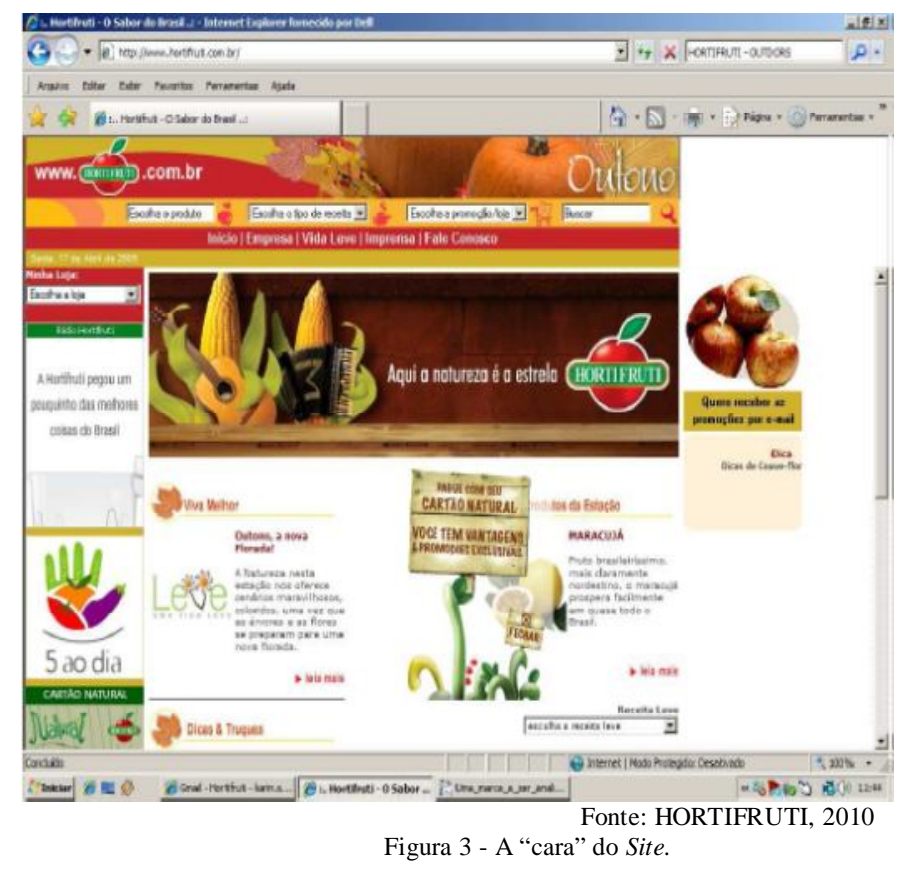

Para ser coerente com o discurso da marca, o site apresenta-se como uma verdadeira salada de frutas: colorido, divertido e agradável. Por meio dele, o público fica sabendo de

\footnotetext{
${ }^{4}$ Disponível em: <http//www.hortifruti.com.br>.
} 
novidades, de eventos, assim como de receitas saudáveis. Entre suas funcionalidades, algumas se destacam:

- programa Receita Leve: grande variedade de receitas elaboradas com frutas, legumes ou verduras;

- profissional especialista em nutrição e saúde à disposição para eventuais dúvidas sobre dietas: o internauta entra no link, digita peso, altura, sexo e idade e obtém informações sobre sua massa corporal e sua classificação - normal, sobrepeso, obesidade leve, moderada ou mórbida -, podendo, inclusive, entrar em contato com esse nutricionista e receber dietas para uma alimentação mais equilibrada e saudável;

- campanha "5 ao dia" (Figura 4): uma mãozinha formada por diferentes produtos lembra ao consumidor a importância do consumo de ao menos cinco tipos de frutas ou hortaliças ao dia. Apresenta um cardápio básico, sob supervisão de um nutricionista, com cinco refeições diárias - café da manhã, lanche, almoço, lanche da tarde e jantar - e a orientação de se acrescentar em cada uma dessas refeições um vegetal, um suco ou uma fruta, justificando que o consumo desses alimentos pode reduzir inúmeras enfermidades e auxiliar as pessoas a viverem mais e melhor (HORTIFRUTI, 2010).

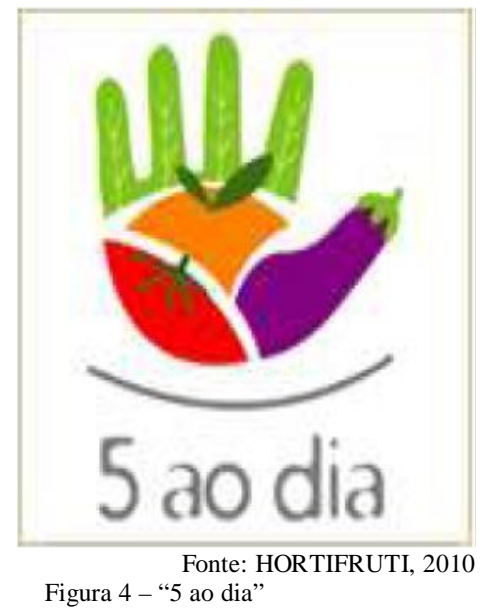

\subsection{Rádio Hortifruti}

A Hortifruti tem uma rádio, cujo conteúdo é veiculado em suas lojas, com músicas de estilos variados, porém, sempre harmoniosas, proporcionando um ambiente agradável. Durante a programação, são feitos "programetes" com dicas de saúde e de propriedades nutricionais de alguma fruta ou hortaliça. 
Acessando o site, o usuário pode sintonizar essa rádio, que tem uma boa conexão e raramente sai do ar. A divulgação do cartão de crédito da Hortifruti, intitulado Cartão Natural (figura 5), é feita durante a programação da rádio. A função do cartão é fidelizar o cliente por meio de prêmios, vantagens, descontos especiais e formas de pagamentos diferenciadas: parcelamento das compras em até duas vezes, sem juros; compras com pagamento em até quarenta dias, sem juros; pagamentos nas Lojas Hortifruti aos finais de semana; pagamentos em qualquer banco, caixa eletrônico e via internet; até dois cartões adicionais grátis; doze datas de vencimento à disposição; pagamento de taxa de manutenção de $\mathrm{R} \$ 3,00$ somente quando houver emissão de fatura; isenção de taxa de anuidade.

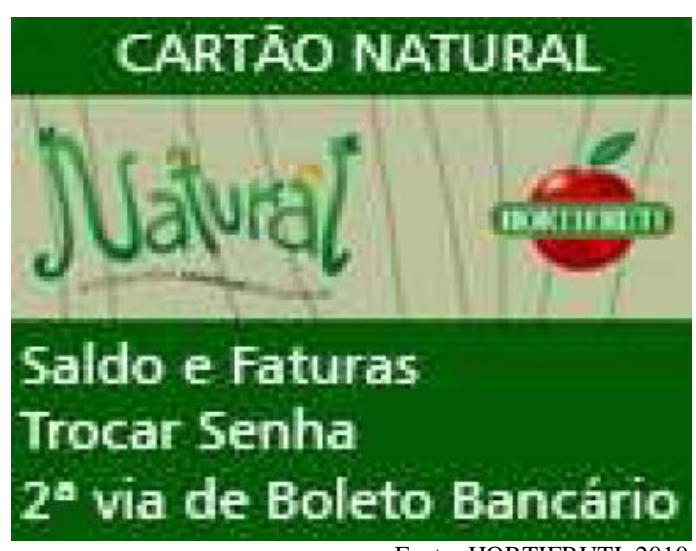

Figura 5 - Cartão Natura

\subsection{Newsletter}

Semanalmente, é enviada uma newsletter, via e-mail, para quem está cadastrado na empresa. Nela, são divulgadas as ofertas da semana (figura 6) e, eventualmente, receitas diferenciadas, com o título Delícia de Oferta (figura 7), que geralmente é uma receita mais elaborada e cujo ingrediente principal é uma fruta da época. 


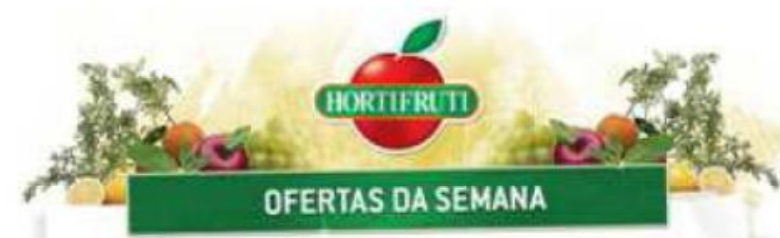

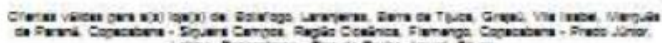

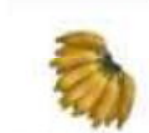

smunums

Rs $1,49{ }_{* 9}$

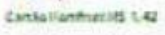

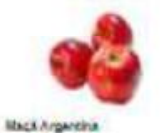

R5 $3,99_{x_{8}}$

Rs $1,49_{x_{s}}$

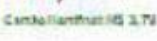

cursolventuris ie

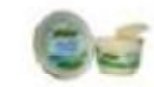

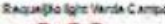
Rs 2,99 iss

-
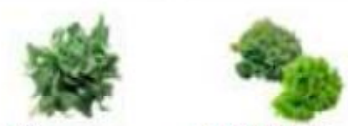

R50,39

Rs 0,39

condicutheses 294

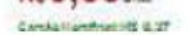

cmastiontusie art

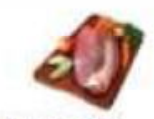

R5 8,99
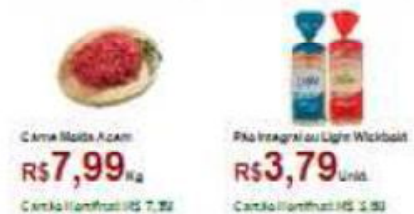

Fonte: HORTIFRUTI, 2010

Figura 6 - Newsletter - Oferta da Semana

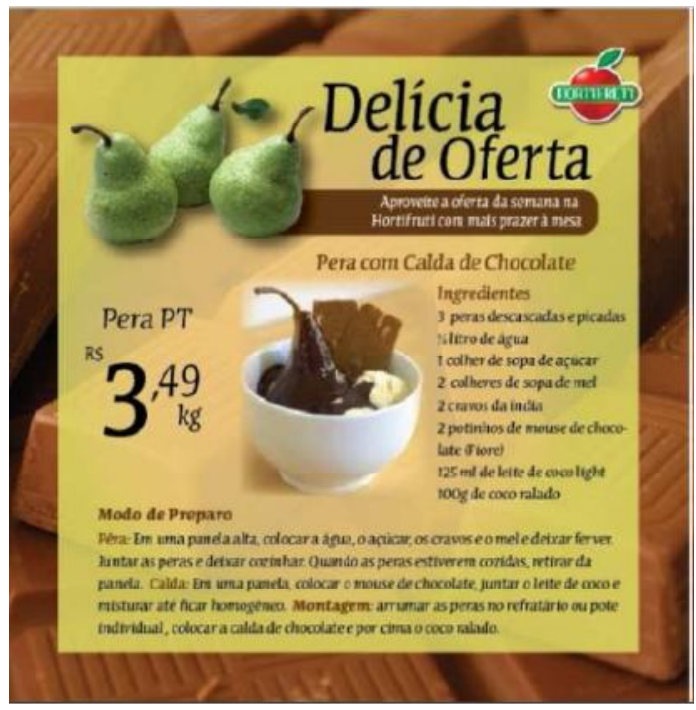

Fonte: HORTIFRUTI, 2010.

Figura 7 - Newsletter - Delícia de Oferta 


\subsection{Televisão}

Comerciais, sempre com os temas da campanha como um todo, são veiculados nos estados onde existem filiais. Também costumam veicular comerciais sazonais e merchandising. Entre estas ações, podemos destacar o Mulheres Possíveis (figura 8), programa apresentado no canal GNT, da Rede Globo, e acompanhado pela revista Quem. Conforme a revista (2007, p. 57):

Ingrid Guimarães e Glória Maria ficaram tão descontraídas batendo papo e comprando legumes que até se esqueceram de olhar para a câmera durante a gravação do programa Mulheres Possíveis, no Hortifruti do Leblon, no Rio de Janeiro. Burburinho no supermercado Hortifruti do Leblon, na Zona Sul do Rio de Janeiro. "Quem é aquela?", pergunta o engraxate Alex, de 14 anos, ao ver a apresentadora Glória Maria numa gravação de Mulheres Possíveis, novo programa da atriz Ingrid Guimarães, que estréia no sábado (27), às $21 \mathrm{~h}$, no canal a cabo GNT. A idéia de Ingrid é desmistificar o glamour que envolve as celebridades e mostrar que elas são gente como a gente. A cada semana, Ingrid abordará um tema por meio do encontro de uma pessoa famosa com uma anônima. Na sexta-feira (19), QUEM acompanhou uma tarde de gravações. As convidadas eram Glória Maria e a radiologista Sandra Ciraudo Aristocolo, que nunca esteve diante das câmeras, mas tem uma coisa em comum com a apresentadora do Fantástico: o consumismo (...) Na saída, o Hortifruti distribui copinhos com salada de frutas. Alex, o engraxate, que não sabia quem era Glória Maria porque nunca assistiu ao Fantástico, garante o seu.

O programa apresentado pela atriz Ingrid Guimarães promove encontro entre famosas e anônimas e põe por terra o glamour que envolve uma celebridade.

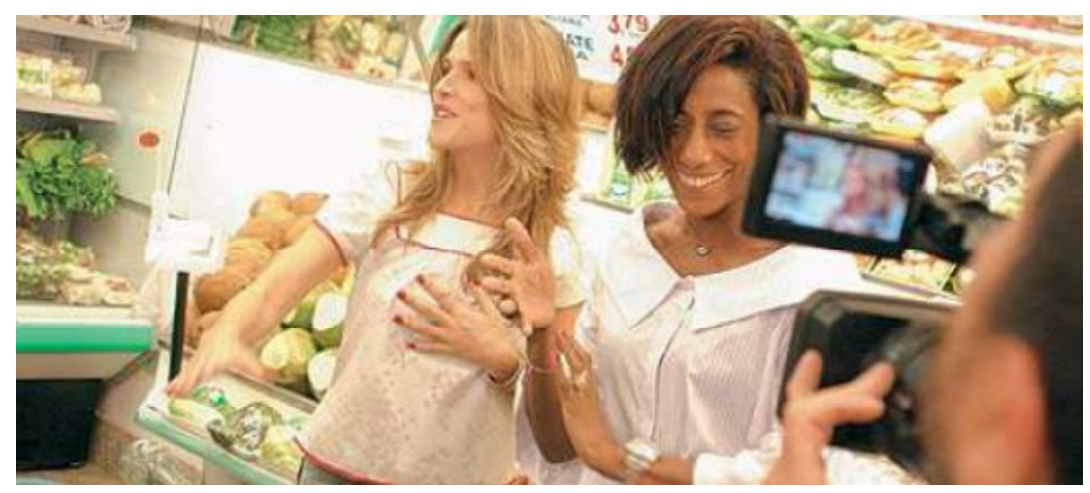

Figura 8 - Ingrid e Glória

Fonte: HORTIFRUTI, 2010 


\subsection{Outdoors}

Os outdoors são colocados em pontos estratégicos e com fluxo grande de pessoas, em vias públicas ou em estações de metrô. As campanhas da empresa são sempre divididas: inicialmente, um outdoor de abertura, apresentando a campanha (figura 9), depois, os demais. As peças publicitárias são apresentadas ao público de forma alegre e divertida, apresentando frutas e verduras como personagens.

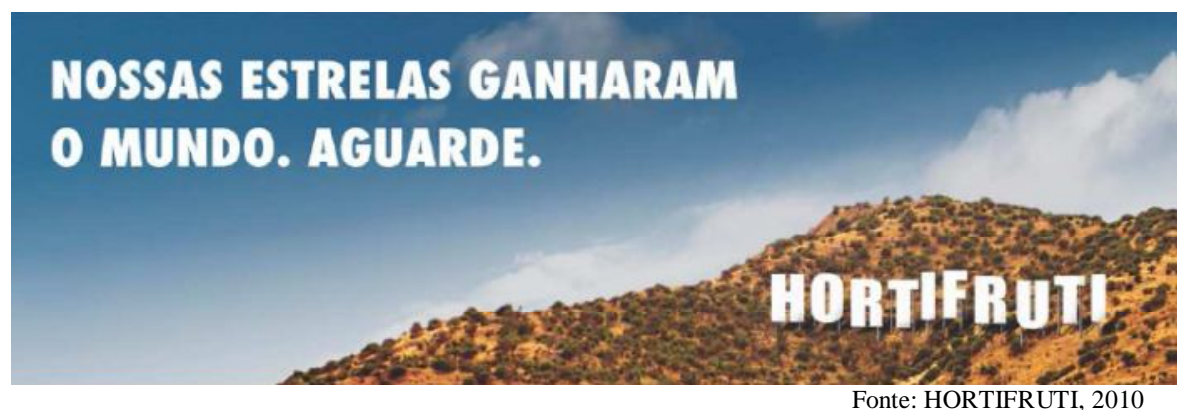

Figura 9 - Outdoor.

Fonte: HORTIFRUTI, 2010

Os outdoors ficam expostos, em média, uma semana e são substituídos, o que os diferencia das outras empresas, que deixam os mesmos outdoors por mais de quinze dias. Os outdoors da Hortifruti são sempre "fresquinhos", assim como seus produtos, o que reforça o discurso da marca.

$\mathrm{Na}$ campanha intitulada Depoimentos, as frutas ou os legumes revelavam seus valores nutricionais ou mesmo suas qualidades e sabores (figuras 10 e 11).

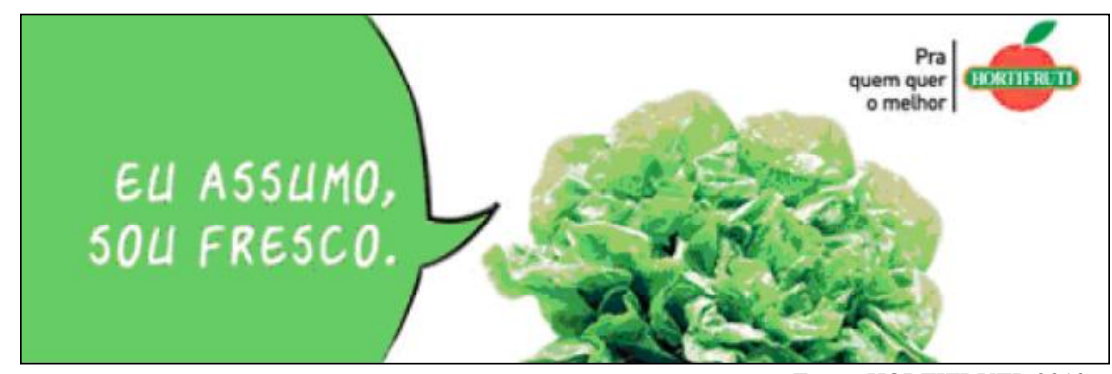

Figura 10 - Campanha Depoimentos

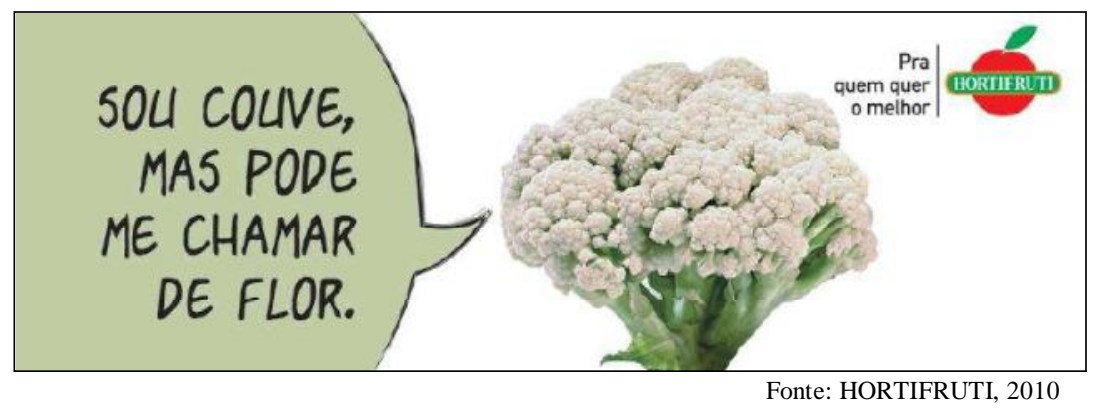

Figura 11 - Campanha Depoimentos 
A campanha Cascas, por sua vez, é uma paródia à revista Caras. Nela, os personagens da Hortifruti, frutas e legumes, com irreverência e graça, revelam seus segredos e peculiaridades e, dessa forma, conseguem surpreender e atrair a atenção do público (figura 12).

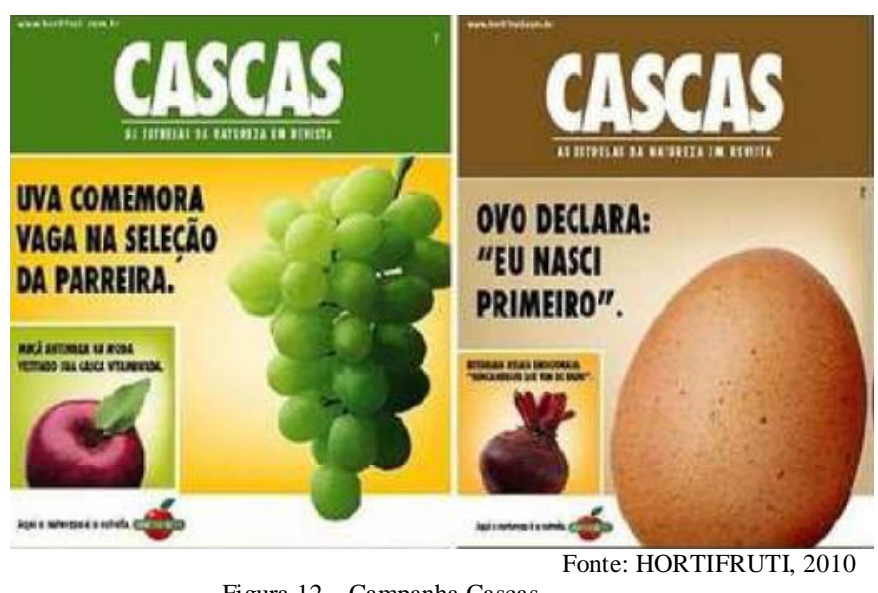

Figura 12 - Campanha Cascas

Observamos uma estratégia igualmente divertida (Figuras 13 a 19) que se apropria de filmes cinematográficos de sucesso. É a campanha Hollywood.

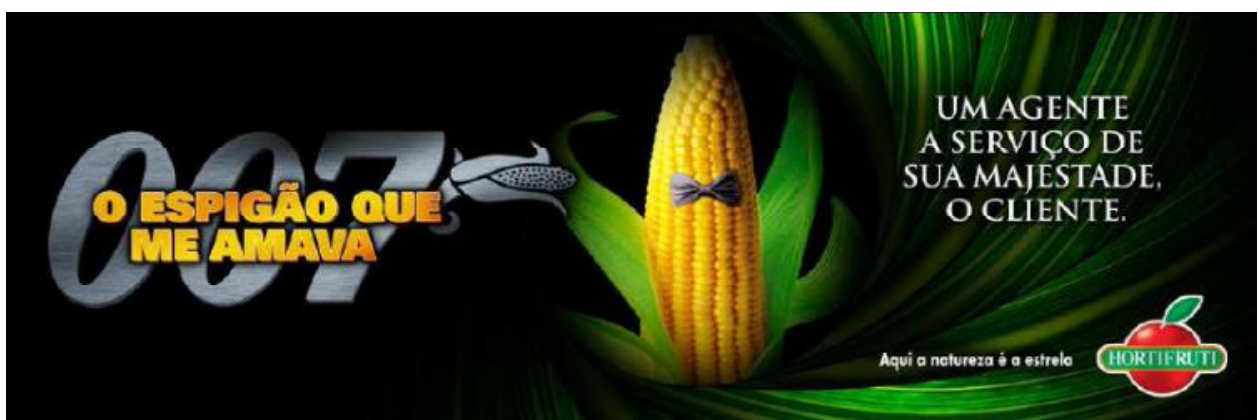

Figura 13 - Campanha Hollywood (milho)

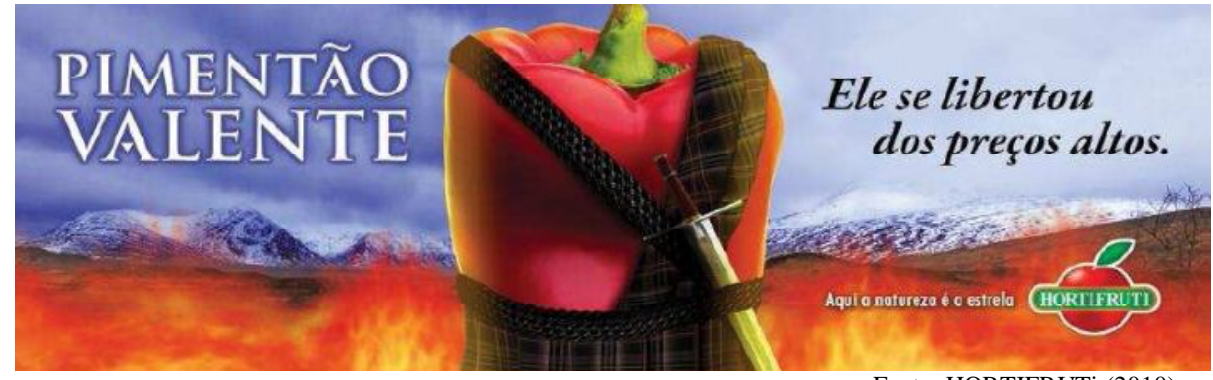

Figura 14 - Campanha Hollywood (pimentão)

Fonte: HORTIFRUTi (2010) 


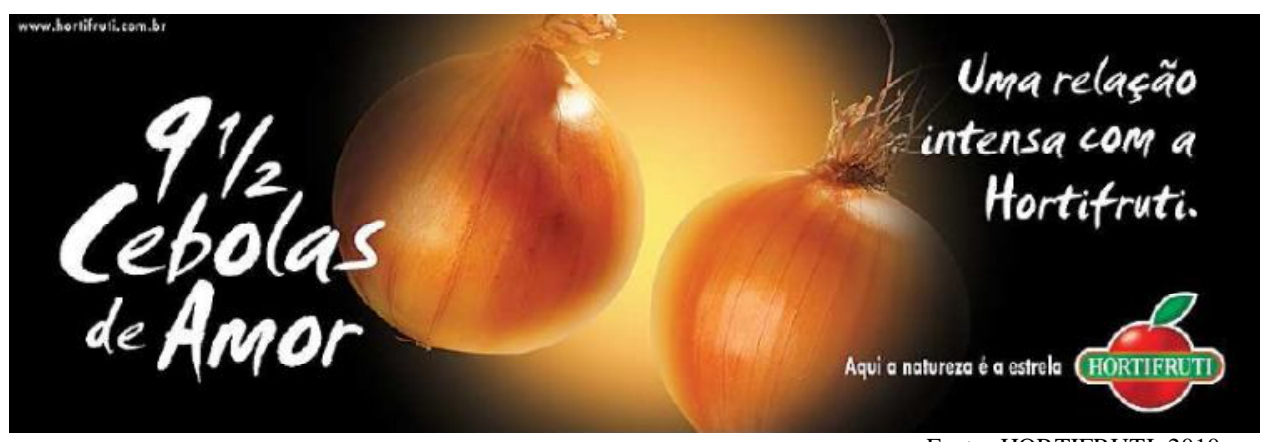

Figura 15 - Campanha Hollywood (cebola)

Fonte: HORTIFRUTI, 2010

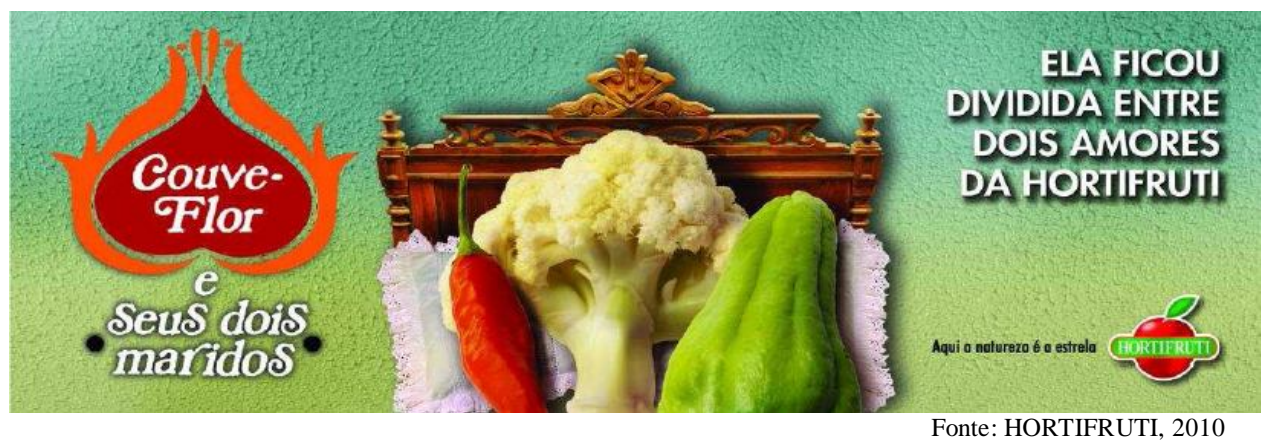

Figura 16 - Campanha Hollywood (couve-flor)

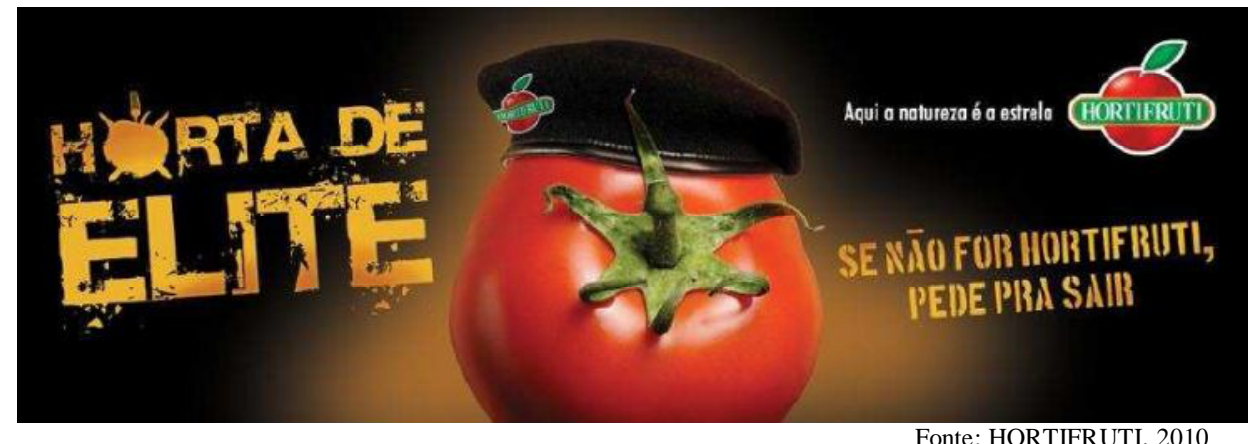

Figura 17 - Campanha Hollywood (tomate)

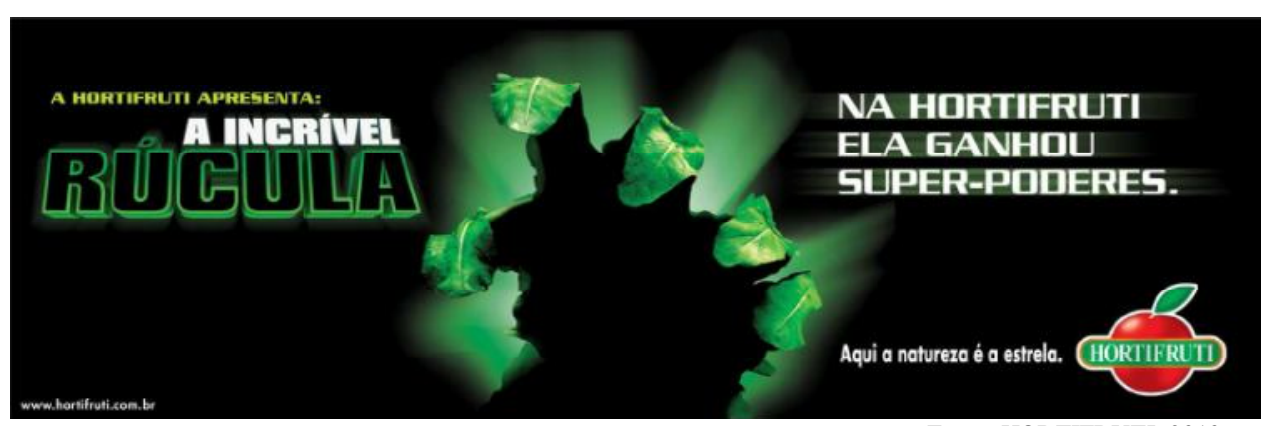

Figura 18 - Campanha Hollywood (rúcula)

Fonte: HORTIFRUTI, 2010 


\section{HOLLYFRUTI}

A campanha Hollywood surgiu numa espécie de continuidade das campanhas anteriores, Depoimentos e Cascas. Devido ao sucesso delas, a Hortifruti, juntamente com a agência MP Publicidade, continuou apostando na ideia de "humanizar" seus produtos, aliás, foi ainda além: suas frutas e legumes, agora, viram astros de Hollywood. Os filmes de sucesso de bilheteria no cinema inspiraram esta campanha da rede de Hortifruti.

Utilizando o imaginário coletivo e os conhecimentos prévios, a campanha busca chamar a atenção dos públicos, provocando seus sentidos para interagir, vivenciar e identificar-se com a marca. Os efeitos positivos dessa estratégia, como empatia, prazer, curiosidade, são transferidos para a marca, que ganha mais valor e conecta-se com seus públicos, fazendo, deles, fãs da marca. Isso tudo é imprescindível, segundo Kreutz e Más (2009, p. 1):

A construção e consolidação de uma marca é um processo complexo, que ocorre dentro de sistemas e microssistemas, contextualizados sóciohistoricamente, e seus investimentos se justificam na medida em que uma marca é, cada vez mais, considerada patrimônio. Uma marca, vista no processo global, cumpre com o seu papel de responsabilidade social, posto que traz desenvolvimento socioeconômico. Uma marca conceituada (Brand Equity) poderá obter mais lucro e este gerar crescimento contínuo da organização.

As organizações buscam estratégias para divulgação de suas marcas $^{5}$, de maneira que sejam percebidas pelos públicos, que façam sentido (positivo) para eles, que se fixem em suas mentes e que sejam as primeiras a serem lembradas e escolhidas, entre outras várias. Utilizam a publicidade que seduz seus públicos, sejam eles consumidores, admiradores ou investidores.

Para Barbosa (2004), um aspecto importante é que, desde a década de 1980, a dimensão expressiva dos produtos tem tido destaque nos anúncios, com a propaganda investindo alto em sonho, aventura, romance, entre outros. A autora defende que a propaganda apela essencialmente para os sentimentos humanos, ou seja, as emoções. Os produtos deixam de ser vendidos e passam a ser comprados pelos consumidores, no sentido de escolhidos. Para que isso se torne possível, os anunciantes precisam convencer seus públicos de que os seus produtos são aqueles que melhor representam os seus anseios e devaneios.

\footnotetext{
${ }^{5}$ Marca é uma representação simbólica (KREUTZ, 2009), percebida pelos multissentidos (LINDSTRON, 2007) e gravada na mente de cada sujeito de maneira única.
} 
De acordo com Carrascoza (2008), a propaganda visa influenciar um determinado público. Recomenda o uso de discursos já conhecidos desse target, tendo como objetivo conseguir uma espécie de atalho, ou seja, facilitar a assimilação com algo que o receptor de alguma forma já conhece.

Seguindo o pensamento do autor, podemos afirmar que a publicidade deve "se fazer valer" do conhecimento do mundo cultural do seu público-alvo, ou seja, do seu imaginário coletivo. A elaboração da publicidade deve levar em conta que este conhecimento é uma ferramenta importante na abertura do caminho da persuasão. Na publicidade, é preciso adaptar essas referências culturais no processo de criação, que podem ser usadas como uma espécie de matéria-prima para a criação publicitária e à disposição do profissional criativo no passado, na atualidade e certamente no futuro.

Para Morin (1997) existe, na cultura de massas, uma homogeneização das idades, uma mixagem de interesses femininos e masculinos, uma infinidade de formas. Segundo o autor (1997, p. 7), “O eixo de cultura de massas deslocou-se. Seu campo ampliou-se, penetrando cada vez mais intimamente na vida cotidiana, no lar, no casal, na família, na casa, no automóvel, nas férias". Nesse contexto, a publicidade se torna parte integrante da cultura de massa.

Para Morin, a cultura de massa carrega uma infinidade de incitações capazes de desenvolver e de despertar necessidades e desejos. Pelo imaginário, pela informação romanceada ou vedetizada da publicidade, efetuam-se impulsos de temas fundamentais que tendem a moldar a vida vivida.

A vida não é apenas mais intensa na cultura de massa. Ela é outra. Nossas vidas cotidianas estão submetidas à lei. Nossos instintos são reprimidos. Nossos desejos são censurados. Mas, a vida dos filmes, dos romances, do sensacionalismo é aquela em que a lei é enfrentada, dominada ou ignorada, em que o desejo logo se torna vitorioso. (MORIN,1997, p. 111).

Morin (1997) também afirma que o cinema foi o primeiro a reunir diversas classes sociais, sejam rurais ou urbanas. Portanto, o cinema representa bem o que pode ser considerado conhecimento cultural, pois tem um alcance muito amplo de público.

Em nosso estudo, verificamos que a campanha Hollywood é uma espécie de carro-chefe da Hortifruti, pois, com ela, a empresa ganhou visibilidade, passou a ser vista e comentada nas ruas e em blogs.

Esta campanha caracteriza-se por ser uma paródia dos filmes de maior sucesso do cinema, dos mais famosos e dos clássicos. A paródia é considerada, por Carrascoza (2008), uma espécie de moeda corrente na criação publicitária, presente no texto, não apenas no título, no 
slogan, na imagem ou em apenas uma parte do texto. Muitas vezes, a paródia pode ser a principal força de uma mensagem publicitária. Para Carrascoza (2008, p. 54), "a adoção da paródia e paráfrases é procedimento típico da propaganda desde os seus primórdios”.

No Brasil, a questão legal do uso de paródias na publicidade, conforme Lei 9.610/98, art. 46, não constitui ofensa aos direitos autorais a reprodução, distribuição e comunicação ao público de obras protegidas, dispensando-se, inclusive, a prévia e expressa autorização do titular e a necessidade de remuneração por parte de quem as utiliza, quando essa utilização for para fins educacionais, didáticos, informativos, de pesquisa ou para uso como recurso criativo.Ou quando feita na medida justificada para o fim a se atingir, sem prejudicar a exploração normal da obra utilizada e nem causar prejuízo injustificado aos legítimos interesses dos autores. No art. 47, são livres as paráfrases e paródias que não forem verdadeiras reproduções da obra originária nem lhe implicarem descrédito. (CULTURA, 2010).

Segundo Malrieu (1996), em uma sociedade, a influência de um sistema coletivo de crenças preexistentes dá-nos a capacidade de compreender a construção dos comportamentos individuais da imaginação. Segundo o autor, o sujeito estabelece relações entre as coisas e os seres, formando uma rede de significações estruturadas e dotadas de estabilidade.

Malrieu (1996) também afirma que a imaginação nos permite conhecer realidades com as quais não estamos acostumados, desperta o desejo de criar novas formas com base em elementos que se encontram à disposição, afirmando sua real existência, não se tratando de imitar, mas, sim, de revelar, de recriar. O indivíduo recria-se, reconstrói-se com as experiências vividas, bem como com as suas aspirações. O sonho, o mito e as artes são formas de expressar, de moldar esta imaginação que, segundo o autor:

É tão indispensável como o olhar, para que tomemos consciência da realidade. Sempre que se fala de imaginação, temos tendência para dizer que ela é a função que representa o que a realidade não pode oferecer: pensamos em algo que se situa para além da percepção. Trata-se de uma visão superficial. A imaginação, numa forma afetiva primária, precede a percepção, afirma-se com o ato de percepção e procura outros preceitos: Antes da percepção há sempre um afeto - uma necessidade, um desejo, um receio, um sentimento. A percepção continua a ser necessária para dar vida à imaginação e fazê-la progredir (MALRIEU,1996, p. 101).

Consciente de que a percepção é guiada pela emoção, os profissionais da Hortifruti se apropriam dos filmes hollywoodianos, não apenas para enviar uma mensagem relevante no tempo e no espaço adequados a um público-alvo, mas para emocionar os públicos, 
independentemente de serem ou não consumidores da marca, criando uma legião de admiradores em qualquer lugar.

Gobé (2002, p. 31) afirma que a conexão emocional da marca com os seus públicos é o que fará a maior e importantíssima diferença: “O elemento emocional é o que proporciona a uma marca a base e a energia para futuras estratégias de negócios - estratégias voltadas para o consumidor”. A preferência por uma marca é o que define a venda e, quando essa preferência é estabelecida, ocorre a "verdadeira" conexão para o sucesso.

Dos inúmeros filmes apropriados pela marca, selecionamos três cartazes para a realização do estudo proposto. São eles: E o Vento Levou, O Diabo Veste Prada e Piratas do Caribe.

Observamos que é comum um mesmo filme ter cartazes cujas imagens são diferentes para a sua divulgação. Isso ocorre para adaptar a linguagem à cultura de cada país. Sendo assim, preocupamo-nos em selecionar as peças cujo vínculo imagético era mais forte. Nossa análise não tem a pretensão de esgotar possibilidades de interpretação semiótica, mas apenas de mencionar alguns dados que consideramos relevantes para exemplificar e compreender a apropriação deles mesmos na publicidade, sua produção de sentido e o efeito sobre a marca.

\subsection{E o Coentro Levou}

E o Coentro Levou é uma paródia ao clássico filme E o Vento Levou, um dos grandes sucessos de bilheteria da década de 40, do século XX (figuras 19 e 20). O conhecimento prévio a ser ativado para associar um título ao outro é reforçado pela produção de sentido que faz inferências, desde a semelhança fonética das palavras "vento" e "coentro" até as semelhanças nos tipos de layout, de logotipos e de cores utilizadas de fundo. O drama de um romance que resiste ao tempo em meio a uma turbulenta história de amor faz analogia ao sabor de um tempero que resiste ao tempo, pois inúmeros temperos surgiram, inclusive os industrializados, mas, mesmo assim, o coentro é insubstituível. O uso generalizado do condimento coentro ocorre não só no Brasil, como em quase todo o mundo, assim como o filme é conhecido internacionalmente. 


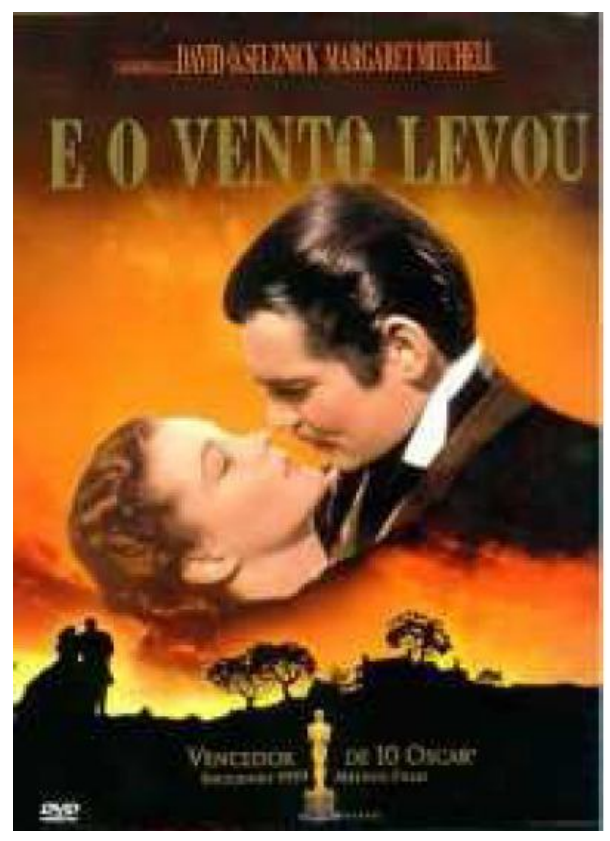

Fonte: PT. SHVOONG, 2010

Figura 19 - ...E o vento levou.

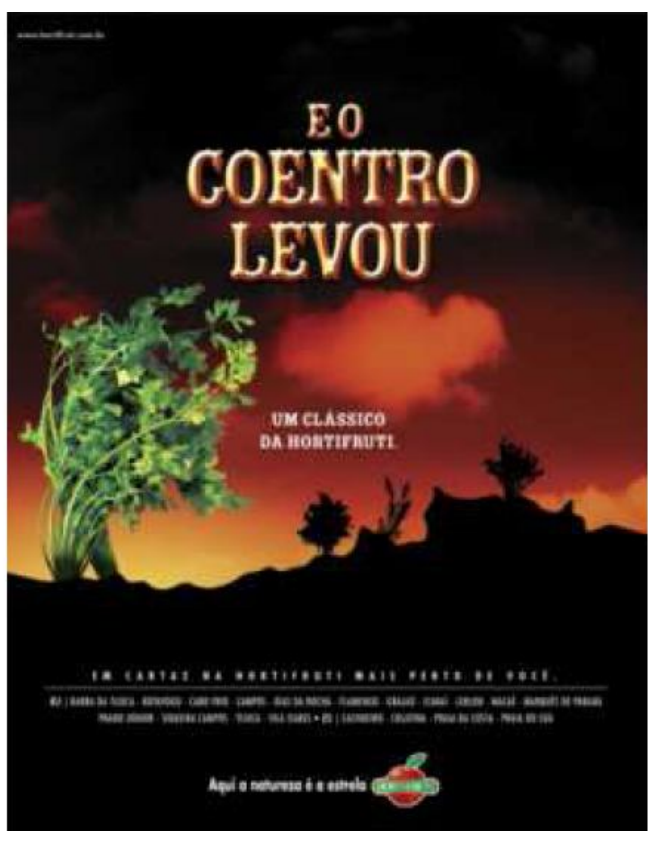

Fonte: HORTIFRUTI, 2010

Figura $20-. .$. E o coentro levou.

A imagem é a de dois ramos de coentro que se entrelaçam em posição envolvente (figura 20), de forma semelhante ao par romântico do filme: a inesquecível personagem Scarlett O’Hara e o galã Rhett Butler, que estão prestes a se beijar. Provavelmente, não ao acaso, o coentro é um aliado do bom hálito, essencial na hora do beijo.

As cores de fundo utilizadas têm tonalidades fortes: preto, vermelho, laranja e cinza esfumaçado - muita fumaça, pois um dos momentos mais marcantes do filme reconstitui um incêndio. A peça publicitária da campanha instiga o leitor a deixar se envolver, a deixar se render pelos encantos e prazeres proporcionados ao paladar pelo sabor do seu protagonista, o coentro. $\mathrm{O}$ sabor desse condimento é clássico e inconfundível, assim como o enredo do filme, que remete a valores tradicionais, como amor à terra, ao país. Fortes emoções também se destacam, como diz o texto de apoio da imagem: "Um Clássico da Hortifruti”.

\subsection{O Quiabo veste Prada}

O Quiabo veste Prada (figura 22) faz referência ao filme O Diabo veste Prada (figura 21). No layout da peça, tudo remete aos cartazes originais do filme: o fundo branco, a tipografia do título, o elegante sapato feminino. O som (fonética) das palavras "quiabo" e "diabo" são muito próximos. Para reforçar a mensagem do título, temos o texto de apoio "Ele entrou no seleto 
mundo da Hortifruti", vinculando, dessa forma, o contexto ao mundo da moda. O quiabo é um legume simples e sem nenhum glamour, mas adquire forma muito requintada ao reproduzir a imagem de um elegante sapato de salto alto. O quiabo, ao conseguir entrar na Hortifruti, provou seu valor, no caso, o seu valor nutricional, pois é rico em vitaminas $\mathrm{A}, \mathrm{C}$ e complexo $\mathrm{B}$, além de fibras que auxiliam o bom funcionamento do intestino. Além disso, o legume de aparência simples é uma excelente fonte de cálcio, sódio, potássio e magnésio, o que o torna ainda mais especial para uma vida saudável e para a manutenção da boa forma. A protagonista do filme, a personagem Andrea, também precisou provar a sua competência para entrar no mundo da moda da sofisticada e maldosa Miranda Priestly.
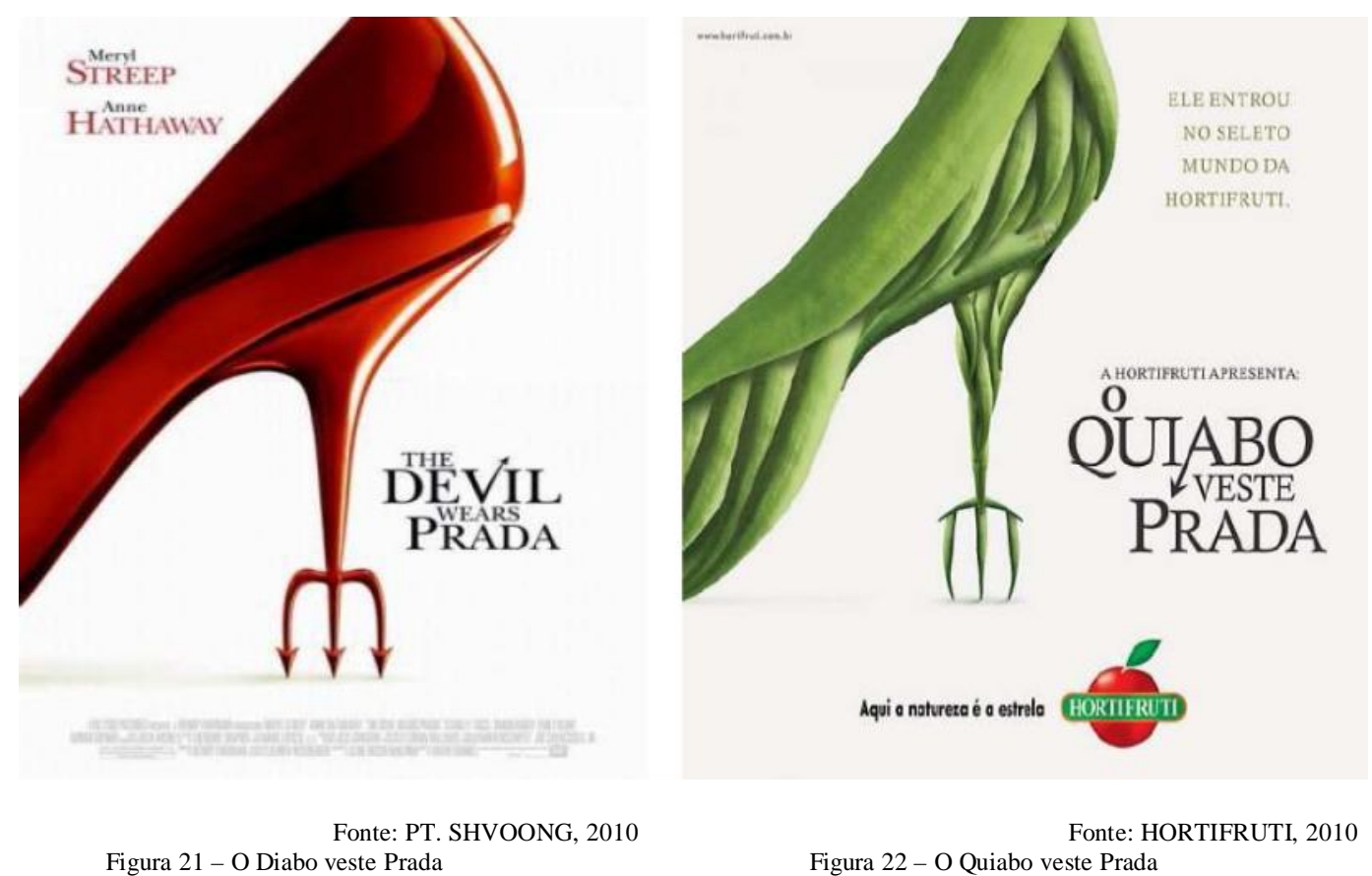

Figura 22 - O Quiabo veste Prada

A peça publicitária tem, no salto do sapato, um tridente do diabo idêntico ao do filme. A famosa marca Prada também se repete. Para o leitor cinéfilo, esta associação é, evidentemente, muito clara. O sapato tem uma forma muito parecida, elegante, de salto alto com tridente diabólico, mas a cor foi trocada. Essa mudança da cor vermelha para o verde com certeza não foi acaso. Além de a cor verde ser complementar à vermelha, pode evidenciar a cor de um legume saudável, leve, nutritivo, como tudo o que é vendido pela empresa Hortifruti. 


\subsection{Batatas do Caribe}

Batatas do Caribe (figura 24) faz paródia ao filme de aventura Piratas do Caribe (figura 23). Esta peça foi um dos outdoors mais comentados, afinal, como criar uma publicidade criativa para um produto tão sem graça como uma batata?

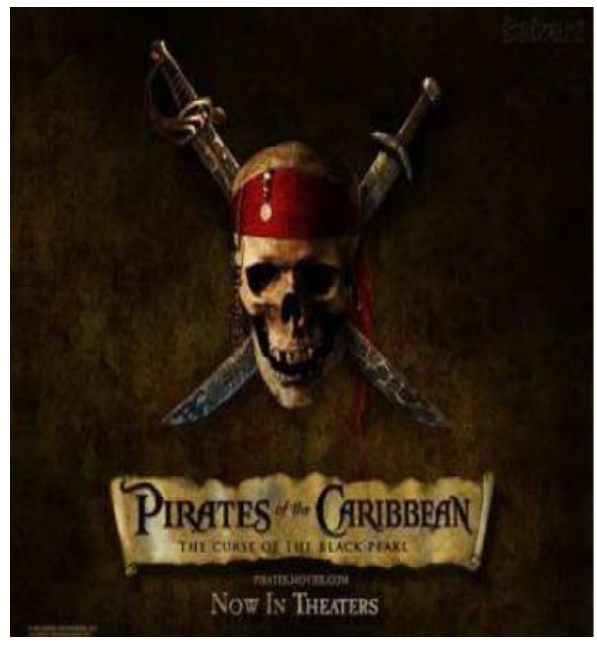

Fonte: ADORO CINEMA, 2010 Figura 23 - Piratas do Caribe

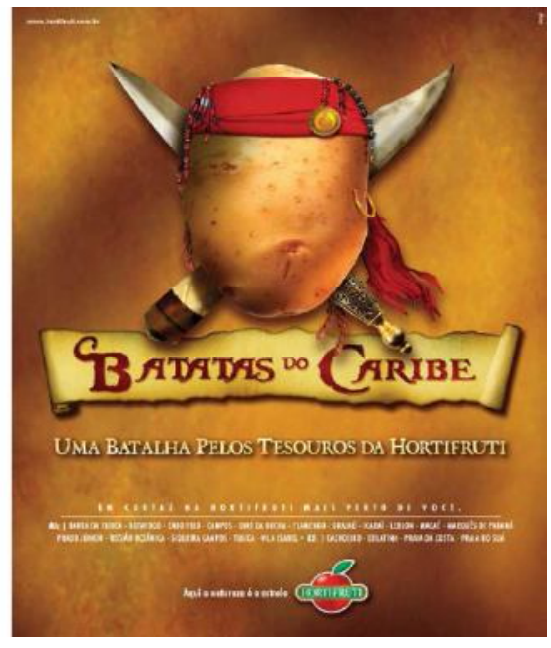

Fonte: HORTIFRUTI, 2010 Figura 24 - Batatas do Caribe

A batata é um tubérculo rico em carboidratos e possui baixa quantidade de gordura. Contém vitaminas do complexo $\mathrm{B}$ e vitamina $\mathrm{C}$ e também é uma fonte importante de amido.

Nesta campanha, a Hortifruti conseguiu dar atributos e adornos a um de seus produtos, a batata, esse vegetal tão singelo e, ao mesmo tempo, tão bem aceito na mesa da maioria dos brasileiros.

A semelhança ao comparar o cartaz da campanha com o cartaz do filme é percebida já num primeiro olhar: cores em tons ocre do plano de fundo, manchas que o fazem parecer desgastado pelo tempo, título escrito numa espécie de papiro antigo e com tipografia que remete a objetos de navio.

O texto complementar "Uma Batalha pelos Tesouros da Hortifruti" ressalta a qualidade e o valor atribuído aos produtos selecionados e comercializados pela empresa. Para o espectador que assistiu ao filme, o texto vai ainda além e relembra as batalhas do personagem protagonista, o pirata Jack Sparrow. O pirata também é recriado pelo lenço vermelho que adorna a batata, tal como na caveira. O estilo pirata é reforçado por miçangas, brinco de argola e medalha dourada.

A simbologia das duas adagas cruzadas significa "proteção" e se repete nos dois cartazes. No filme, é proteção contra a maldição do Pérola Negra, pois, quando a lua surge no céu, todos da tripulação são transformados em esqueletos vivos. A batata, por sua vez, é muito versátil na culinária. Pode-se interpretá-la como uma espécie de salvação, de "proteção" do cardápio, pelas 
diversas receitas em que este ingrediente se encaixa: muito utilizada em saladas, como acompanhamento de carnes (frango, peixe e boi), como purês ou como fritas. O vegetal batata faz a alegria da garotada que adora fritas e, igualmente, adora o filme de ação e de aventura.

\section{Análise crítica das estratégias e considerações finais}

Considerando o exposto, podemos afirmar que a Hortifruti realiza a comunicação integrada de marca e que suas estratégias de comunicação, como site, newsletter, televisão, outdoors podem ser consideradas adequadas e em sintonia com os propósitos da empresa. Nesse sentido, a Hortifruti mostrou, com resultados mensuráveis de seu faturamento no ano de 2010 (R \$ 480 milhões, conforme MADUREIRA, 2010), que suas estratégias de comunicação estão conseguindo alcançar os seus objetivos.

Fator determinante para esse sucesso foi a união da empresa com a agência publicitária escolhida. A empresa, juntamente com a agência, criou várias formas de se diferenciar das demais, utilizando, em suas campanhas, referências que fazem parte do imaginário coletivo dos brasileiros, a exemplo da campanha Revista Cascas, que faz sátira à revista de fofocas Caras, e da campanha Hollywood, que faz paródias dos filmes de Hollywood.

Acreditamos que, com suas campanhas, a empresa Hortifruti consegue envolver seu público-alvo. Para dar destaque a um produto tão popular e vendido em feiras ao ar livre, sem conforto algum, é preciso agregar-lhe valor, um algo a mais. Para um produto aparentemente sem graça, como frutas e hortaliças, a empresa conseguiu, juntamente com a agência MP Publicidade, do Espírito Santo, criar um novo conceito, uma nova forma de anunciar.

A Hortifruti, com suas estratégias comunicacionais, consegue a fidelidade emocional dos fãs da marca, que inclui até mesmo pessoas que, apesar de não terem acesso às lojas por fatores como distância, poder aquisitivo ou outros, tornam-se simpatizantes da marca, o que, sem dúvida, aumenta o seu valor. Esse fator pode ser verificado nos comentários postados na internet sobre os outdoors, sobre a rádio, entre outros. Segundo Rozanski (2002), isso é definido como "o efeito aura", que é mais do que atender às necessidades, é ter afeição, história comum e confiança no outro.

Constatamos que, hoje, para uma marca conseguir se consolidar no mercado, é necessário trabalhar de forma multissensorial, com os cinco sentidos humanos: visão, audição, tato, olfato e paladar. Em outras palavras, é preciso uma comunicação voltada para a "experienciação" do público. Constatamos também que a marca precisa trabalhar com a emoção das pessoas, surpreender, divertir, fazendo com que a ela sejam associadas coisas positivas da vida dos 
públicos. Dessa forma, consegue-se uma proximidade entre ambos, uma espécie de conexão emocional que vira fidelidade.

Nosso estudo evidencia que é possível fazer uma publicidade diferenciada capaz de consolidar uma marca, desde que haja sintonia entre os valores da empresa (marca), sua comunicação e a imagem percebida por seus públicos.

Conscientes da impossibilidade de esgotar nossas análises sobre as inúmeras estratégias comunicacionais da empresa Hortifruti, encontramo-nos satisfeitos por compreender que a marca necessita da comunicação estratégica e criativa como ferramenta principal para ancorar, para dar suporte ao negócio. Da mesma forma, o branding torna-se imprescindível para gestionar o discurso multimodal da marca para conseguir e manter um pacto afetivo com os seus públicos.

\section{Referências}

\section{A RAZÃO. Disponível em: <http //www.arazao.net/condimentos.html> Acesso em: 30 ago. 2010.}

ADORO CINEMA. Disponível em: <http://www.adorocinema.com/fil mes/piratas-docaribe/> Acesso em: 30 ago. 2010.

AL, Ries; TROUT, Jack. Posicionamento: a batalha pela sua mente. 8. ed. São Paulo: Thompson/Pioneira, 2003.

BARBOSA, L.. Sociedade de consumo. Rio de Janeiro: Ed.Jorge Zahar, 2004.

BAUER, M.; GASKELL, G.. Pesquisa qualitativa com texto, imagem e som: um manual prático. 2. ed. Petrópolis: Vozes, 2002.

BRAISTON. Blog Rascunho. 2008. Disponível em: <blograscunho. blogspot.com/2008/01/brainstorm.html〉. Acesso em: 16/05/11

BROCHAND, B. et al. Publicitor. Lisboa: Publicações D. Quixote LTDA, 1999.

CARNEIRO, A.. Outdoors do Hortifruti. 2008. Disponível em: <http://newserrado.com/2008/05/09/outdoors-do-horti-fruti/>. Acesso em: 16 mai. 2009.

CARRASCOZA, J. A. Do caos à criação publicitária: processo criativo, plágio e ready-made na publicidade. São Paulo: Saraiva, 2008.

COBRA, M.. Sucesso em marketing: casos brasileiros. São Paulo: Atlas, 1991.

CULTURA. Disponível em: <www.cultura.gov.br?consultadireitoautoral/wp-content/uploads/2010/06/Lei9610_ConsolidadA_Consulta_Publica.pdf >Acesso em $: 17 / 11 / 2010$.

DONDIS, D. A. A sintaxe da linguagem visual. 2. ed. Editora São Paulo.: Martins Fontes, 2000

DURAND, G. As estruturas antropológicas do imaginário. São Paulo: Martins Fontes., 1997.

EMEDIX. Disponível em: 〈http//emedix.uol.com.br/dia/ali006_1f_quiabo.php〉 Acesso em: 30 ago. 2010.

GOBÉ, M. A emoção das marcas: conectando marcas às pessoas. Rio de Janeiro: Editora Campus Ltda, 2002.

GUIMARÃES, R. Branding: uma nova filosofia de gestão. Revista ESPM. Março/abril, 2003.

HOLMER, A. M. S. A campanha publicitária do "Iguatemi 20 anos de estilo" sob o viés da Teoria Culturológica, [s/d].

HORTIFRUTI. 2009/2010. Disponível em: 〈http:/www.hortifruti.com.br〉. Acesso em: 16 mai. 2009.

KREUTZ, E. de A.; FERNANDEZ, F. J. Branding e as tendências da comunicação mercadológica. Lajeado-RS/Brasil: UNIVATES, Santiago/Chile: Universidad Mayor, 2009.

KREUTZ, E. de A.; MACHADO, M. B. A marca e os múltiplos olhares. Lajeado-RS: UNIVATES, Novo Hamburgo: FEEVALE, 2009.

KREUTZ, E. As principais estratégias de construção da Identidade Visual Corporativa. Porto Alegre: PUCRS, 2001. (Dissertação).

LINDSTROM, M. Brand sense: a marca multissensorial. Porto Alegre: Bookman, 2007.

MADUREIRA, D. Como uma quitanda seduziu investidores. Clipping fornecido pela assessoria de impressa da Hortifruti por e-mail no dia 6/9/2010.

MALRIEU, P. A construção do imaginário. Lisboa: Instituto Piaget, 1996.

MORIN, E. Cultura de massas no século XX: neurose: o espírito do tempo. 9. ed. Editora Forense Universitária, 1997.

MP PUBLICIDADE. 2009. Disponível em: 〈http://www.mppublicidade.com.br〉. Acesso em: 16 maio 2009.

PENN, G. Análise semiótica de imagens paradas. In: BAUER, Martin; GASKELL, George. Pesquisa qualitativa com texto, imagem e som: um manual prático. 2.ed. Petrópolis: Vozes, 2002, p. 319-342.

PIEDRAS, E. R. Publicidade, imaginário e consumo: anúncios no cotidiano feminino, 2008.

PT. SHVOONG. E o vento levou. Disponível em: <http://pt.shvoong.com/entertainment/movies/1922627-vento-levou-1939/> Acesso em: 30 ago. 2010. 2010.

O diabo veste prada. Disponível em: <http://pt.shvoong.com/travel/websites-onlinecommunities/ 493819-filme-diabo-veste-prada/> Acesso em: 30 ago.

REVISTA Isto é Dinheiro. Hortifruti. São Paulo: Editora Três, 21 de maio de 2003. Edição nº 299.

REVISTA QUEM. Gente como a Gente. São Paulo: Ed. Globo, 24 de outubro de 2007. Edição $n^{\circ} 372$.

ROZANSKI, B.W. Os fãs da marca e o "efeito aura" In: HSM Management. São Paulo: 31, mar/abril 2002. Pág. 84-90.

SANTAELLA, L. ; WINFRIED, N. Imagem cognição, semiótica e mídia. São Paulo: Editora Iluminuras Ltda., 2001.

SILVA, J. A. D. Campanha Hollywood. [mensagem pessoal]. Mensagem recebida por < julianefc@ msbnet.com.br> em 04 de out. de 2010.

SILVESTRE, C.; KREUTZ, E. ; MÁS FERNÁNDEZ, F.; VIEIRA, J.; MÜLLER, T. O discurso da marca: o caso Natura e NaturaPura. In: VIII Congresso LUSOCOM. Lisboa: Lusófona, 2009.

SUA PESQUISA. Disponível em: <http://www.suapesquisa.com/alimentos/batata.htm>. Acesso em: 30 ago. 2010.

THOMPSON, J. B. Ideologia e cultura moderna. Petrópolis: Vozes, 1995.

VIEGAS, L. Campanha Hollywood. [mensagem pessoal]. Mensagem recebida por <julianefc@ msbnet.com.br> em 20 de setembro de 2010.

VIEIRA, S. Marca: o que o coração não sente os olhos não vêem: reflexos sobre marketing e ética. 2. ed. Rio de Janeiro: PUC - Rio, 2004.

VOCÊ ACREDITA EM QUÊ? Disponível em: <http://voceacreditaemque.wordpress.com/2009/05/02/crenca-e-origem-das-simpatias/>. Acesso em: 30 ago. 2010.

YAMAGUISHI. Disponível em: 〈http://www.yamaguishi.com.br/receitas_dicas/dica_quiabo.asp〉. Acesso em: 30 ago. 2010. 